International Journal of Economics, Business and Accounting Research (IJEBAR)

Peer Reviewed - International Journal

Vol-3, Issue-4, 2019 (IJEBAR)

E-ISSN: 2614-1280 P-ISSN 2622-4771

https://jurnal.stie-aas.ac.id/index.php/IJEBAR

\title{
A MODEL OF MIXED STRATEGIC ORIENTATIONS BASED ON ENVIRONMENT IN ACHIEVING ATOUGH PERFORMANCE OF SMES
}

\author{
Darmanto $^{1)}$, Budiyono ${ }^{2)}$, Sri Wardaya ${ }^{3)}$, Lilis Setyarini ${ }^{4)}$, Basuki Sri Rahayu ${ }^{\text {5) }}$ \\ Institute of Economic Science St. Pignatelli Surakarta 1)3) 4)5) \\ College of Economics AAS Surakarta ${ }^{2)}$
}

\begin{abstract}
This study aims to design a model in achieving superior performance of MSMEs. The mixed strategic orientations of demography, economy and cultural values are used to design this model. The population of this study consists offood MSMEs in Central Java. The 750 samples are chosen with convenient sampling technique. Data analysis method used the Crosstab Analysis and Structural Equation Model (SEM). The result of this research is a model explaining that demography, economy and cultural values influence antecedent variables of customer orientation, dimension of strategic orientations and organizational performance. The antecedent variables affect customer orientation; the dimension of strategic orientations affects performance; Variable of change of capacity unmoderated customer and competitor orientations on innovation orientation. Variable of competitive advantage unmediated customerand competitor orientations on performance.
\end{abstract}

Keywords: $\quad$ Mixed strategic orientations, Demography, Economy, Cultural values, Performance

\section{Introduction}

The development success in Indonesia isdominated more by material and quantitative measures. As a result, the development even creates inequality among community groups and regions. The Progress that occurs is not rooted in culture, so that, in turn, this can fade away the identity of the nation. Any advances which are based on technologies and economies generally exploit natural resources. This will, inevitably, cause worries in the future. The development of the Indonesian nation has low resilience to anticipate various changes. Some Indonesians tend have individualistic behavior and like to use natural resources unwisely. This, then, generates an exclusive economy. Indonesia cannot get out of the political-economic traps that makeit become a consumer nation. Overcoming this problem needs a strategic developmentthat directly touches the lower and middle class societies that are developing micro, small and medium enterprisesthat are often termed SMEs. This research is trying to formulate a comprehensive model that can be applied to solve the economic problems of MSMEs in Indonesia.

In searching the national and international scientific journals the researchers find there are six models that can be used to improve the quality of MSMEs, but these are in fact not comprehensive. On this occasion the researchers try to formulate a comprehensive model. Model 1 isperformance improvement with strategic orientation of customer. This model states that improving the quality of SMEs can be done by applying the customer orientation (Zehir\&Acar 2011). The antecedent variableof customer orientation consists of entrepreneurial orientation, marketing-based reward system and learning orientation (Basile, 2012; Aljaz, 2012).. Model 2 is 
International Journal of Economics, Business and Accounting Research (IJEBAR)

Peer Reviewed - International Journal

Vol-3, Issue-4, 2019 (IJEBAR)

E-ISSN: 2614-1280 P-ISSN 2622-4771

https://jurnal.stie-aas.ac.id/index.php/IJEBAR

performance improvement with market and innovation orientations. Competitor orientation influences the innovation orientation. A strong market orientation has links to incremental innovation and the strong market orientation affects innovation ( Lewrick 1, Omar2 \& Robert, 2011). Model 3 is performance enhancement with mixed strategic orientations. Strong customer and competitor orientations have a positive effect on incremental performance and a strong customer orientation has impact on performance (Grawe, 2009). Relevently, the research of Jhonson, Dibrell and Eric (2009), states that innovation orientation influences the performance of the manufacturing industry. Jhonson et al. (2009) state that integrated innovation orientation influences the performance of manufacturing companies. Model 4 is performance improvement with mixed strategic orientations is mediated by competitive advantage and is moderated by change orientation; Model 4 is a combination of model 1, 2 and 3. Model 5, performance improvement with mixed strategic orientations based on demography. This model is the improvement of model 4 by adding demographic variable, which consists of gender, age, education, and experience. Model 6 is performance improvement with mixed strategic orientations based on economy and culture. This model is an improvement of model 4 by adding economic and cultural value variables.

Economic variables consist of government, price, and growth. Cultural value variables consist of cultural values of Java, China and Padang. The model created in this study is a model accommodating all existing models. As far as their investigations on the previous studies, the researchers have not found such a comprehensive model. This model includes variables of demography, economy, cultural values and mixed orientations. These four variables affect performance. Demographic variables consist of education, age and experience. Economic variables consist of government, price, and growth. Cultural variables consist of Javanese, Chinese and Padang cultures. The orientation mix consists of customer, competitor, innovation, change, and competitive advantage orientations. This model is named

A Model of Mixed Strategic Orientations Based on Environment in Achieving ATough Performance of SMEs. The advantages of this model are very comprehensive, they are elaborating the antecedent, independent, dependent, control, mediation and moderation variables

\section{Materials and Methods}

This study is conducted on food MSMEs in Central Java, consisting of 29 regencies and 6 cities. Central Java is chosen because MSMEs in this province have the same characteristics as ones in other parts of Indonesia. The research uses cross section time, because it is done nowadays, and not directly related to the past or the future researches. This type of research belongs to an applied research, because its result is a model that can be applied by business actors. (Sekaran, 2010). The unit of analysis in this study includes individuals. The population of this research isMSMEs of food sector in Central Java.The number of MSMEs always increases but no institution has complete and appropriate data about this. The number of sample is 750 units of selected food MSMEs.

This study applies convenient sampling method in 4 cities, namely Salatiga, Semarang, Surakarta, Tegal and 8 regencies, namely Boyolali, Brebes, Kendal, Klaten, Kudus, Sragen, Sukoharjo, Semarang. This research uses analysis technique of Crosstab and Structural Equation 
International Journal of Economics, Business and Accounting Research (IJEBAR)

Peer Reviewed - International Journal

Vol-3, Issue-4, 2019 (IJEBAR)

E-ISSN: 2614-1280 P-ISSN 2622-4771

https://jurnal.stie-aas.ac.id/index.php/IJEBAR

Modeling (SEM). The results the Crosstab analysis is used to know the influence of demographic environment, economic and cultural values variables on antecedent variables of customer orientation, independent variable and dependent variable. Analysis of Structural Equation Modeling (SEM) indicate the effect degree of independent variable on dependent variable, the role of change orientation variable as a mediation variable and competitiveness variable as a mediation variable.

\section{Results}

The result of Crosstab analysis between demographic, economic,cultural value variables and orientation variables of entrepreneur, reward and learningis presented in Table 1 as follows:

\begin{tabular}{|c|c|c|c|c|c|c|c|c|c|}
\hline & \multicolumn{3}{|c|}{ Entrepreneur } & \multicolumn{3}{|c|}{ Reward } & \multicolumn{3}{|c|}{ Learning } \\
\hline Demography: & $\begin{array}{c}\text { Chi } \\
\text { Square }\end{array}$ & $\begin{array}{r}\text { Signifi } \\
\text { cance }\end{array}$ & Information & $\begin{array}{c}\text { Chi } \\
\text { square }\end{array}$ & $\begin{array}{l}\text { Signifi } \\
\text { cance }\end{array}$ & Information & $\begin{array}{c}\text { Chi } \\
\text { square }\end{array}$ & $\begin{array}{c}\text { Signifi } \\
\text { cance }\end{array}$ & Information \\
\hline Education & 113,86 & , 000 & Sig & 119,11 & ,000 & sig & 119,09 & , 000 & Sig \\
\hline Experience & 11,169 & .025 & $\mathrm{Sig}$ & 31,559 & .000 & $\mathrm{Sig}$ & 13,389 & .010 & Sig \\
\hline Age & 11,144 & .025 & Sig & 34,249 & .000 & $\mathrm{Sig}$ & 15,996 & .003 & Sig \\
\hline \multicolumn{10}{|l|}{ Economy: } \\
\hline Government & 10,499 & .001 & Sig & 12,895 & .000 & Sig & 19,92 & .000 & Sig \\
\hline Price, & 7,252 & ,007 & Sig & $9,272^{\mathrm{a}}$ & .003 & $\mathrm{Sig}$ & 15,275 & .000 & Sig \\
\hline Revenue & $3,581^{\mathrm{a}}$ & .023 & Sig & $9,587^{\mathrm{a}}$ & .002 & Sig & $8,907^{\mathrm{a}}$ & .003 & Sig \\
\hline Growth & $8,610^{\mathrm{a}}$ & .003 & Sig & 11,212 & .001 & Sig & 16,753 & .000 & Sig \\
\hline \multicolumn{10}{|l|}{ Culture: } \\
\hline Javanese & 17,234 & .000 & Sig & 30,317 & .000 & Sig & 28,561 & .000 & Sig \\
\hline Chinese & 16,032 & .000 & Sig & 24,868 & .000 & Sig & 26,805 & .000 & Sig \\
\hline Padang & 18,109 & .000 & Sig & 27,366 & .000 & Sig & 29,625 & .000 & Sig \\
\hline
\end{tabular}

Source: Primary data processed in 2018

Based on the analysis results presented in Table 1 can be said demographic, economi, cultural values have positive and significant influence on Variable orientation intreprenour, Variable orientation reward, learning. Crosstab analysis result between demographic, economic, cultural values variables and orientatonvariables of customer, competitor and innovationis presented in Table 2 as follows:

\begin{tabular}{|c|c|c|c|c|c|c|c|c|c|}
\hline & \multicolumn{3}{|c|}{ Customer Orientation } & \multicolumn{3}{|c|}{ Competitor Orientation } & \multicolumn{3}{|c|}{ Innovation Orientation } \\
\hline Demography: & $\begin{array}{c}\text { Chi } \\
\text { square }\end{array}$ & $\begin{array}{l}\text { Signifi } \\
\text { cance }\end{array}$ & Information & $\begin{array}{c}\text { Chi } \\
\text { square }\end{array}$ & $\begin{array}{l}\text { Signific } \\
\text { ance }\end{array}$ & Information & $\begin{array}{c}\text { Chi } \\
\text { square }\end{array}$ & $\begin{array}{l}\text { Signifi } \\
\text { cance }\end{array}$ & $\begin{array}{r}\text { Inform } \\
\text { ation }\end{array}$ \\
\hline Education & 104,85 & .000 & Sig & 97,770 & .000 & Sig & 130,98 & .000 & Sig \\
\hline Experience & 25,017 & .000 & Sig & 24,814 & .000 & Sig & 17,628 & .001 & Sig \\
\hline Age & 42,842 & .000 & Sig & 23,523 & .000 & Sig & 22,283 & .000 & Sig \\
\hline \multicolumn{10}{|l|}{ Economy: } \\
\hline Government & $9,031^{\mathrm{a}}$ & .003 & Sig & $3,769^{a}$ & .000 & Sig & 45,381 & .000 & Sig \\
\hline
\end{tabular}


International Journal of Economics, Business and Accounting Research (IJEBAR)

Peer Reviewed - International Journal

Vol-3, Issue-4, 2019 (IJEBAR)

E-ISSN: 2614-1280 P-ISSN 2622-4771

https://jurnal.stie-aas.ac.id/index.php/IJEBAR

\begin{tabular}{|c|c|c|c|c|c|c|c|c|c|}
\hline Price, & $6,056^{\mathrm{a}}$ & .014 & Sig & $3,974^{\mathrm{a}}$ & .000 & sig & 38,009 & .000 & Sig \\
\hline Revenue & $8,404^{\mathrm{a}}$ & .004 & Sig & $5,343^{\mathrm{a}}$ & .000 & sig & 25,116 & .000 & Sig \\
\hline Growth & $8,666^{\mathrm{a}}$ & .003 & Sis & $5,337^{\mathrm{a}}$ & .024 & sig & 39,005 & .000 & Sig \\
\hline \multicolumn{10}{|l|}{ Culture: } \\
\hline Javanese & 14,094 & .000 & Sig & 57,176 & .000 & Sig & 42,634 & .000 & Sig \\
\hline Chinese & 21,267 & .000 & Sig & 11,979 & .001 & Sig & 54,142 & .000 & Sig \\
\hline Padang & 23,277 & .000 & Sig & 12,141 & .000 & Sig & 58,519 & .000 & Sig \\
\hline
\end{tabular}

Source: Primary data processed in 2018

Based on the results of the analysis presented in Table 2, it can be said that demographic, economy, cultural values have significant positive effect on customer Variable orientation, competitor variable orientation, and innovation.The result of Crosstab analysis between demographic, economic, cultural values variables, and Orientation Variables of change, Competitive excellence, performance is presented in Table 3 as follows:

\begin{tabular}{|c|c|c|c|c|c|c|c|c|c|}
\hline & \multicolumn{3}{|c|}{ Change of capacity } & \multicolumn{3}{|c|}{ Competitive Advantage } & \multicolumn{3}{|c|}{ Performance } \\
\hline Demography: & $\begin{array}{l}\text { Chi } \\
\text { square }\end{array}$ & $\begin{array}{l}\text { Signifi } \\
\text { cance }\end{array}$ & Information & $\begin{array}{c}\text { Chi } \\
\text { square }\end{array}$ & $\begin{array}{l}\text { Signifi } \\
\text { cance }\end{array}$ & Information & $\begin{array}{l}\text { Chi } \\
\text { square }\end{array}$ & $\begin{array}{c}\text { Signifi } \\
\text { cance }\end{array}$ & $\begin{array}{r}\text { Inform } \\
\text { ation }\end{array}$ \\
\hline Education & 139,51 & .000 & Sig & 133,24 & .000 & Sig & 132,30 & .000 & Sig \\
\hline Experience & 16,187 & .003 & Sig & 20,003 & .000 & Sig & 16,821 & .002 & Sig \\
\hline Age & 19,828 & .003 & Sig & 19,087 & .000 & Sig & 21,180 & .000 & Sig \\
\hline \multicolumn{10}{|l|}{ Economy: } \\
\hline Government & 34,442 & .000 & Sig & 36,241 & .000 & Sig & 43,372 & .000 & Sig \\
\hline Price, & 28,131 & .000 & Sig & 31,841 & .000 & Sig & 36,185 & .000 & Sig \\
\hline Revenue & 16,552 & .000 & Sig & 16,552 & .000 & Sig & 23,786 & .000 & Sig \\
\hline Growth & 27,497 & .000 & Sig & 31,033 & .000 & Sig & 37,241 & .000 & Sig \\
\hline \multicolumn{10}{|l|}{ Culture: } \\
\hline Javanese & 42,634 & .000 & Sig & 44,584 & .000 & Sig & 54,971 & .000 & Sig \\
\hline Chinese & 40,234 & .000 & Sig & 42,098 & .000 & Sig & 52,032 & .000 & Sig \\
\hline Padang & 43,857 & .000 & Sig & 45,826 & .000 & Sig & 56,299 & .000 & Sig \\
\hline
\end{tabular}

Source: Primary data processed in 2018

Based on the results of the analysis presented in Table 3 it can be said that the variables Demographic, Economy, Cultural Values have positively and significantly affect the change of Capasity organizational, Competitive Advantage and Performance

\section{Structural Equation Modeling (SEM) Analysis}

The result of feasibility test of SEM model shows that the model in this research is fit. The most important things in this feasibility test are Chi square and probability. Chi square should be small and this result proves so, that is 1362.72 . Probability should be $\geq 0.05$, and the result in this research is 0.184 . Consequently, the model of this research is fit.

The result of SEM analysis of the Effect of Entrepreneurship,marketing-based reward and learning orientations on Customer Orientation is presented with $\mathrm{CR}$ and $\mathrm{P}$ values in Table 5 as follows: 
International Journal of Economics, Business and Accounting Research (IJEBAR)

Peer Reviewed - International Journal

Vol-3, Issue-4, 2019 (IJEBAR)

E-ISSN: 2614-1280 P-ISSN 2622-4771

https://jurnal.stie-aas.ac.id/index.php/IJEBAR

\begin{tabular}{|llllll|}
\hline \multicolumn{2}{|c|}{ Table 5 CR and P Values of the Effect of Entrepreneurship, Marketing-based Reward and Learning Orientation } \\
on Customer Orientation
\end{tabular}

Source: Primary data processed in 2018

The SEM analysis result ofthe influence of customer, competitor,and learning on orientation. The SEM analysis resultof the Influence of customer and competitor orientation on innovation orientation is presented with $C R$ and $P$ value in Table 6 as follows:

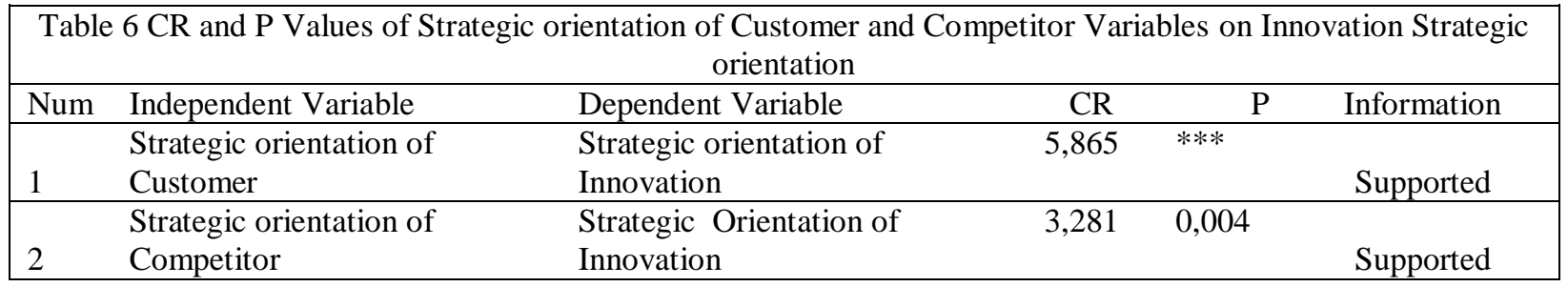

Source: Primary data processed in 2018

The SEM analysis result onthe influence of Strategic orientation Customer, Strategic orientation Competitor, on Strategic orientation of Innovation. The SEM analysis result of Organizational change of capabilities moderate the effect of customer orientation and customer orientation on innovation is presented with $\mathrm{CR}$ and $\mathrm{P}$ value in Table 7 as follows:

\begin{tabular}{|l|ccc|}
\hline \multicolumn{4}{|l|}{ Table 7.CR And P Values Organizational Change Capabilities Moderate the Effect of Customer and Competitor } \\
Orientation on Innovation Orientation
\end{tabular}

Source: Primary data processed in 2018

Table 8.The Influence of Customer and Competitor Orientation on Competitive Advantage 
International Journal of Economics, Business and Accounting Research (IJEBAR)

Peer Reviewed - International Journal

Vol-3, Issue-4, 2019 (IJEBAR)

E-ISSN: 2614-1280 P-ISSN 2622-4771

https://jurnal.stie-aas.ac.id/index.php/IJEBAR

\begin{tabular}{|lllccc|}
\hline No & Dependen t Variable & Variable Independen & CR & P & Information \\
1 & Competitive advantage & Customer orientation Strategi & 3,357 & 0,002 & Supported \\
2 & Competitive advantage & Competitor orientation Strategi & 2,796 & 0,045 & Supported \\
\hline
\end{tabular}

Source: Primary data processed in 2018

Based on Table 8 it can be argued that customer and competitive orientation strategies have a positive and significant effect on competitive advantage. Competitive advantage strategy influences performance of MSMEs

Table 9 The Influence of Competitive Advantage Competes on Performance

\begin{tabular}{|c|c|c|c|c|c|}
\hline No & Dependen Variable & Independen Variable & $\mathrm{CR}$ & $\mathrm{P}$ & Keteragan \\
\hline 1 & Performance & Competitive advantage & 2,767 & 0,046 & Supported \\
\hline
\end{tabular}

Source: Primary data processed in 2018

Based on Table 9 it can be said that competitive advantage positively and significantly influence on performance The SEM analysis result of the Influence of customer and competitor orientations on performance mediated by competitive advantage with $\mathrm{CR}$ and $\mathrm{P}$ value is presented in Table 10.

Table $10 \mathrm{CR}$ and P Values of the influence of customer and competitor orientation on performance mediated by competitive advantage

\begin{tabular}{|l|l|l|l|l|}
\hline Num & Independent Variable & Directly & Indirectly & Information \\
\hline 1 & Strategy of customer orientation & CR 3,094, P 0,008 & CR 2,767 P 0,046 & Un Mediating \\
\hline & & CR 2,831 P 0,035 & CR 2,767 P & Un Mediating \\
\hline
\end{tabular}

Source: Primary data processed in 2018

Based on Table 10 can be said customer orientation strategy and competitor orientation strategy have a significant positive effect on performance.

The SEM analysis result of the Influence of customer, competitor, Competitive Advantage Orientationson Performance is presented with CR and P values in Table 11 as follows:

\begin{tabular}{|lllllc|}
\hline \multicolumn{5}{|c|}{ Table11 .CR and P Values of Strategic orientation Variables of Customer, Competitor and Competitive } \\
Advantage on Performance
\end{tabular}

Source: Primary data processed in 2018 
International Journal of Economics, Business and Accounting Research (IJEBAR)

Peer Reviewed - International Journal

Vol-3, Issue-4, 2019 (IJEBAR)

E-ISSN: 2614-1280 P-ISSN 2622-4771

https://jurnal.stie-aas.ac.id/index.php/IJEBAR

\section{Discussion}

The environmental demography, economy, and cultural values have impacts on entrepreneurship, reward and learning orientations. The result of research on the influence of demographic, economic, cultural variables on Entrepreneurship, reward and learning orientationsshows a positive and significant influence. This result is in line with the research of Luca, C. \&Tingting, W.(2012). This result is not contrary to the research of Amin, A. et al., (2011),A.Emre Demirci1, (2013) and Thorben CK, (2013). The results of their researches indicate that demographic, economic and cultural variables have a positive effect on entrepreneurship, Reward and learning orientation. Demographic, economic, and cultural environments have effects on the vaviables of mixed strategic orientations.

The result of the research on strategic orientation variables of demography, economy and culture shows a positive and significant impact. This resultis consistent to the research ofKotler, P., (2010); Prayudi, Puji Lestari, (2011), Nabsiah, A., W., Elham Ran., Tan S. S, (2011);Abdul, T.S et al.(2012); CristianOdagiu, PhD, Simone N., Lengler, J., Pilar, M.F .. 2013). While the research of Christian, P. \& Wagner, J., (2012)indicates that women are more active, and younger performance are more innovative. Demographic, economic, and cultural environments have effects on the performance of SMEs.

The result of research onthe influence of demography, economy, and culture on the performance of MSMEs shows a positive and significant influence. This result is in accordance with ones of Danieule, S.(2012, A. Emre Demirci1, (2013), Yoshitaka Yamazaki, (2012); Abdul, TS et al., (2012), which state that demographic, economic and cultural variables have positive and significant influence on performance .The Entrepreneurship, reward and learning variables influence the strategic orientation of customer. The research result on the influence of the orientation variables of entrepreneurship, reward and learningon customer orientation shows a positive and significant effect. This result is in line with the research of Omar, Nwanko and Richards (2008); Ma'atoofi \& Tajeddini (2010); Andreas and Marcus(2010); Cristina(2011); Basile (2012); Gagne (2009; Devlin et al, (2011); Hatice, (2012) stating that entrepreneurial behavior enhances the orientations of customer, market, and customer values for companies operating in a dynamic environment. Meanwhile, (Schindehutte et al., 2008; Micheels, Eric \& Gow, 2009; Wencong, et al., 2011) state that Entrepreneurship, reward system and learning have effects on customer orientation.

Strategic orientation variables of customer and competitor influence thestrategic orientation of innovation. The result of SEM analysis on the effect of customer orientation on innovation shows a positive and significant influence. This result is not contrary to the research result of Ana et al.(2011) stating that customer and competitor-oriented companies will enhance exploration and exploitation innovations. The competitor orientation has a significant effect on the ability of innovation of exploitation. The innovation ability of exploitation affects the performance of the present period, while the ability of exploration innovation influences the future performance.

The strategic change of capacity moderates the influence of customer and competitor strategic orientations on innovation strategic orientation. The result states that the orientation of change unmoderate the influence of customer and competitor strategic orientations on innovation 
International Journal of Economics, Business and Accounting Research (IJEBAR)

Peer Reviewed - International Journal

Vol-3, Issue-4, 2019 (IJEBAR)

E-ISSN: 2614-1280 P-ISSN 2622-4771

https://jurnal.stie-aas.ac.id/index.php/IJEBAR

strategic orientation. This result does not deviate from the results of researches by Oppen (2009); Gravenhost et al. (2010) which state that organizational change ability influences innovation orientation, the stronger the organizational change ability is, the higher the orientation of innovation will be; and the weaker the organizational change ability is, the lower the orientation of innovation will be. The change of strategic orientation immoderate the influence of customer and competitor strategic orientations on innovation strategic orientation.The capability of organizational change is an independent variable of innovation orientation variables. Customer and competitor strategic orientations affect the competitive advantage.

The results of this study indicate that the strategy of customer and competitor orientation positively and significantly influence on competitive advantage. The higher level of customer and competitor orientation will lead to higher competitive advantage. These results are in line with the research (Grawe, 2009; Lewrick 1, Omar2 \& Robert, 2011), suggesting market orientation influences competitive advantage. The results of this study are in line with research by Jhonson et al. (2009) the results of his research stated that customer orientation influences the competitive advantage of manufacturing companies. These results are indeed logical, businesses that have many customers, can satisfy customers, paying close attention to customers, considering competitors, out perform competitors will have competitive advantage. So competitive advantage can be improved by improving customer and competitor orientation strategy.

The Competitive advantage strategy influences SMEs' performance. This study shows the result that competitive advantage positively and significantly affects Performance. This result is consistent with the results of researches byAna et al.(2011); Francesco \& r.(2011) stating that competitive advantage consists of product and market advantages, both of which affect performance.Thus Competitive advantage strategy influences MSMEs' performance. The higher the level of competitive advantage then the performance of MSMEs will be higher. These results are very logical, SMEs that have a high competitive advantage level has a high level of performance. Performance levels can be improved by increasing the competitive advantage. SMEs that have a high competitive advantage will have a good performance.

The strategy of competitive advantage unmediates thestrategic orientations ofcustomerand competitor on the performance of MSMEs. The result of this study indicates the competitive advantage unmediates customer and competitor strategic orientation on performance. This result contradict the research of Luke and Ferrell (2009), which states that customer and competitor orientations have no effect on new product development, but improve performance. Cost competitive advantages in the process and the use of machines affect performance (Ana et al., 2011; Francesco \& r, 2011). Competitive advantage does not mediate the effect of customer orientation on organizational performance but only as an inherent variable of organizational performance

Competitive advantage strategy unmediates customerand competitor orientations on performance. Customer, and competitor orientations should increase Performance SMEs. Customer and competitor orientations that do not increase competitive advantage will not improve performance. The orientations of customer, and competitor that do not increase competitive advantage may not be in accordance with the customers'will or the competitors' 
International Journal of Economics, Business and Accounting Research (IJEBAR)

Peer Reviewed - International Journal

Vol-3, Issue-4, 2019 (IJEBAR)

E-ISSN: 2614-1280 P-ISSN 2622-4771

https://jurnal.stie-aas.ac.id/index.php/IJEBAR

actions, so that the implementation needs to be reviewed. Competitive advantage positively and significantly impact on performance. The higher keunggula estranged the higher performance of SMEs. This is logical, SMEs that have a high competitiveness will have a good performance. The results of this study can be accepted common sense.

The mixed strategic orientations influence the performance of SMEs. The result of SEM test states that strategic orientations have significant and positive effects on MSMEs'performance. This result is in line with the research by Lin et al. (2008) thatfinds a positive relationship between market orientation on innovation and the company's performance. The competitive advantage has positive and significant effects on performance. This result is also in line with the researches of (Gurhan et al., 2011), stating that the competitive advantage strategy influences the performance of MSMEs. Mix strategy of orientation variable that affect the performance of customer orientation strategy, competitors, innovation, organizational change ability and competitive advantage.

\section{Conclusion}

The Model of Mixed Strategic Orientations Based on Environment in Achieving aTough Performance of MSMEs is designed based on:

Demographic environment consists of gender, age, education and experience; Economic environment consists of impact, price, income and government; Cultural value environment consists of Javanese, Chinese and Padang cultural values;Antecedent Variable oriented on customer consists of entrepreneurship, Reward and learning orientations.

The mixed strategic orientations consist of customer, competitor, innovation, change and competitive advantage orientations. Environmental variables affect the antecedent variables of customer orientation, mixed strategic orientations and performance. The mixed strategic orientations influence positively and significantly on performance. Change orientation variable moderates the effects of customer and competitor orientations on innovation orientation. Variable of competitive advantage mediates the orientations of customer, competitor and innovation on performance

\section{Limitation}

This research is conducted with population and sample of food MSMEs in Central Java, so the use of the model is still limited in the case of food SMEs. This model is not suitable for MSMEs clothing or other business sectors.

\section{Recommendation}

The future researchers can use different populations, samples or sampling methods, for example the research including samples of clothing business, and using purposive sampling method.

\section{References}

A.Emre Demirci1, 2013. Strategic Representation of an Abstract Reality: Spiraling Relations between Organizational Culture and Innovativeness, :Journal of Management and Strategy Vol. 4, No. 3 
International Journal of Economics, Business and Accounting Research (IJEBAR)

Peer Reviewed - International Journal

Vol-3, Issue-4, 2019 (IJEBAR)

E-ISSN: 2614-1280 P-ISSN 2622-4771

https://jurnal.stie-aas.ac.id/index.php/IJEBAR

Abdul T.S., Hashim R., Karuthan C.K.M., 2012, Malaysian Fine Dining Restaurants: Profiling of Consumers' Demographics and Dining-Out Behavior and Determination of

Amin A., Hassan M.F., Ariffin M., 2011, Knowledge Sharing:Two-Dimensional Motivation Perspective and the Role of Demographic Variables, "Journal Int. Journal of Global Environmental Issues", 11(3-4).

Ana, L. Dionysis, S. \& Carmen, L. 2011. Innovative Capabilities: Their Drivers and Effects on Current and Future Performance, Journal of Business Research. Vol.64, p. 34-48

Andreas, K., Harald, S. 2013. The role of employees for post-entry firm growth, Springer in its Journal Small Business Economics Vol. 41: 3 Pp 733-755

Basile, A.,2012. Entrepreneurial Orientation in Smes: Risk-Taking To Entering Psychology and Business, Vol. 7, p.87-103

Bartle, P. ,2010. Sixteen Elements of Organizational Capacity Components that Change as it gets Stronger, Lokakarya Handout, p.1-24

Christian, P., Wagner, J. (2012). Is innovative firm behavior correlated with age and gender composition of the workforce? Evidence from a new type of data for German enterprises, Working Paper Series in Economics and Institutions of Innovation with number 291

Cristian, S.,2011. The Marketing Entrepreneurship and the SMEs Competitiveness, Journal of Knowledge Management, Economics and Information Technology, Vol.1,p. 8-2

Danieule, S. (2012). Italian Medium-Sized Enterprises and The Fourth Capitalism, Journal of Applied Economic Sciences. Vol.VII, 4.Pp. 437-446

Devlin, S. Kudenko, D. \& Grzes, M. (2011). An Empirical Study of PotentialBased Reward Shaping and Advice in Complex, Multi-Agent Systems, Artile Provided by World Scientific Publishing Co. Pte. Ltd. its Journal, Vol.14. p. 251-278.

Francesco, B, \& Mario, P, (2011). Engines of Growth. Innovation and Productivity in Industry Groups, Journal Structural Change and Economic Dynamics, Vol.22. p. 27-69

Gagne, M. (2009). A model of knowledge-sharing motivation, Human Resource Management, Vol. 48. p. 571-589

Gravenhorst,. K.M. B., Werkman, R.A. \& Boonstra J.J. (2009). The Change Capacity of Organisations,: General Assessment and Five ConPgurations University of Amsterdam, The Netherlan

Grawe.S.J, (2009), The Relationship Between Strategic Orientation, Service Innovation, and Performance, Emerald Group Publishing Limited Economics", 5(1).

Gurhan, G, Gunduz, U, Kemal, K, \& Lutfihak, A, (2011). Effects of Innovation Types on Firm Performance, Journal of Production Economics, Vol. 133p. 662-676.

Hotice, C. (2012). The Effluence of Intrinsic and Extrinsic Rewards on employee results: an empirical analysis in Turkish manufacturing industry, faculty of ecinimic and administrative sciences in its journal, vol. 3. p. 54-67.

Jhonson, A.J. Dibrell, C.C. \& Eric, H. (2009). Market Orientation, Innovativeness, and Performance of Food Companies, Journal of Agribusiness, Vol. 27. p. 85-106

Kotler P., 2010, Marketing Management Analysis, Planning, Implementation, and Control, (12th Ed.), Englewood Cliff, NJ, New Jersey: Prentice-Hall Inc

Lewrick, M.1, M. Omar2 \& Robert L.W. Jr, (2011). Market Orientation and Innovators' Success: an Exploration of the Influence of Customer and Competitor Orientation Technol, Journal Management Innovasion, Vol. 6. p.48-62 
International Journal of Economics, Business and Accounting Research (IJEBAR)

Peer Reviewed - International Journal

Vol-3, Issue-4, 2019 (IJEBAR)

E-ISSN: 2614-1280 P-ISSN 2622-4771

https://jurnal.stie-aas.ac.id/index.php/IJEBAR

Li, Y., Wei, Zhou. \& Liu, Y. (2010). Strategic orientations, knowledge acquisition,and firm performance: The perspective of the vendor in cross-borderoutsourcing, Journal of Management Studies, Vol. 47.p. 1457-1482.

Luca C., Tingting W., 2012, A Study of Small Business Owners' Personal Characteristics and the Use of Marketing Information in the Food and Drink Industry: A ResourceBased Perspective, "International Journal on Journal System Dynamics",

Luke and .Ferrell (2009), Providing Customer Input During The New Product Development Process? customer orientation, and ultimately increase of its average competitor in the information sharing but has little or no effek, Marketing Management journal vol.9 no.2 pp28-38

Ma'atoofi, A.R. \& K.Tajeddini. (2010). The Effect of Entrepreneurship Orientation on Learning Orientation and Innovation: A Study of SmallSized Business Firms in Iran, International Journal of Trade, Economics and Finance, Vol. 1. p. 254-260.

Micheels, Eric T. \& Gow, H.R. (2009). Do Market Oriented Firms Demonstrate Clarity on Their Value Discipline? Evidence from Illinois Beef Producers Article provided by International Food and Agribusiness Management Association (IAMA), Journal International Food and Agribusiness Management Review, Vol. 12. p. 34-45

Nabsiah, A., W., Elham R., Tan S. S.,.Ramayah, T. , 2011. Top of Form Bottom of Form Relationship between environmental volunteers' demographic characteristics and their green purchase behaviour: evidence from Penang (Malaysia)Inderscience Enterprises Ltd Journal Int. J. of Global Environmental Issues.Vol.11: 3/4 Pp: 299-309. Yoshitaka Y., 2012, Learning style and confidence: an empirical

Nwanko, S. \& Richards, D. (2008). Determinants of International Entrepreneurship of UK Companies, Journal World Review of Entrepreneurship, Management and Sustainable Development. Vol. 4, p. 118

Prayudi, Puji Lestari, (2011),Uji model kompetensi komunikasi bisnis lintas budaya: studi di kalangan pengusaha perak etnik Jawa dan Padang di Yogyakarta dan Padang: laporan hasil penelitian hibah fundamental

Oppen C.V., 2009, Organizational Capabilities as the Key to Sustainable Innovation, "Journal World Review of Entrepreneurship, Management and Sustainable Development", 6.

Schindehutte, M., Morris, M. H., \& Kocak, A. (2008). Understanding Market Driving Behaviour: The Role of Entrepreneurship, Journal of Small Business Management, Vol. 46. p. 4-2

Sekaran U., Roger B., 2010, Research Methods for Business's Skill Building Approach, (5th Ed.), John Wiley and Sons, Ltd. Publication.

Thorben C. K. (2013). Imagine Being a Nice Guy: A Note on Hypothetical vs. Incentivized Social Preferences, Christoph Philipps-Universität Marburg, Faculty of Business Administration and Economics, Department of Economics BührenMAGKS Papers on Economics with number 201349.

Wencong Ma., Guilong. Z. \& Yu, H. (2011). Learning Orientation, Process Innovation, and Firm Performance in Manufacturing Industry School of Business Administration, South China University of Technology, Guangzhou, China, Advances information science and sevice science vol. 3. p.1-4.

Yoshitaka Y., 2012, Learning style and confidence: an empirical investigation of Japanese investigation of Japanese employees, Paper provided by Research Institute, International University of Japan, Working Papers NO. EMS_2012_0.

Zehir C \& A. Acar (2011): Strategic Orientations and Their Effects on Firm Performance in Turkish Family Owned Firms JournalEurasian Business Review, Vol. 1. p. 18-36. 